\author{
Correspondence \\ Olga V. Golyshina \\ olg@helmholtz-hzi.de \\ Brian J. Tindall \\ bti@dsmz.de \\ Peter N. Golyshin \\ p.golyshin@bangor.ac.uk
}

\section{Acidiplasma aeolicum gen. nov., sp. nov., a euryarchaeon of the family Ferroplasmaceae isolated from a hydrothermal pool, and transfer of Ferroplasma cupricumulans to Acidiplasma cupricumulans comb. nov.}

\author{
Olga V. Golyshina, ${ }^{1}$ Michail M. Yakimov, ${ }^{2}$ Heinrich Lünsdorf, ${ }^{1}$ \\ Manuel Ferrer, ${ }^{3}$ Manfred Nimtz, ${ }^{1}$ Kenneth N. Timmis, ${ }^{1}$ Victor Wray, ${ }^{1}$ \\ Brian J. Tindall ${ }^{4} \dagger$ and Peter N. Golyshin ${ }^{1,5,6} \dagger$

\footnotetext{
${ }^{1}$ Helmholtz Centre for Infection Research, Inhoffenstrasse 7, 38124 Braunschweig, Germany

${ }^{2}$ Istituto per l'Ambiente Marino Costiero, CNR, Spianata San Raineri 86, 98122 Messina, Italy

${ }^{3}$ Institute of Catalysis, CSIC, Marie Curie 2, Campus Cantoblanco, 28049 Madrid, Spain

${ }^{4} \mathrm{DSMZ}$ - Deutsche Sammlung von Mikroorganismen und Zellkulturen GmbH, Inhoffenstrasse 7b, 38124 Braunschweig, Germany

${ }^{5}$ School of Biological Sciences, Bangor University, Gwynedd LL57 2UW, UK

'University of Wales, Aberystwyth and Bangor University Initiative for Research Management for Rural Environments (CIRRE), UK
}

A novel acidophilic, cell-wall-less archaeon, strain $\mathrm{V}^{\top}$, was isolated from a hydrothermal pool on Vulcano Island, Italy. The morphology of cells was observed to vary from pleomorphic to coccoid. The temperature range for growth of strain $\mathrm{V}^{\top}$ was $15-65{ }^{\circ} \mathrm{C}$ with an optimum at $45{ }^{\circ} \mathrm{C}$. The pH for growth ranged from $\mathrm{pH} 0$ to 4 with an optimal at $\mathrm{pH}$ 1.4-1.6. Strain $\mathrm{V}^{\top}$ was able to grow aerobically and anaerobically, oxidizing ferrous iron and reducing ferric iron, respectively. The isolate grew chemo-organotrophically with yeast extract and yeast extract with glucose as the sources of energy and carbon. The molar $\mathrm{G}+\mathrm{C}$ content in the DNA was $36 \mathrm{~mol} \%$. 16S rRNA gene sequence analysis demonstrated that strain $\mathrm{V}^{\top}$ was a member of the family

Ferroplasmaceae, order Thermoplasmatales, phylum Euryarchaeota, showing sequence identities of $100 \%$ with Ferroplasma cupricumulans $\mathrm{BH}^{\top}{ }^{\top}, 95.4 \%$ with Ferroplasma acidiphilum $\mathrm{Y}^{\top}, 94 \%$ with Picrophilus torridus DSM $9790^{\top}$ and $92 \%$ with Picrophilus oshimae DSM 9789 ${ }^{\top}$. 16S rRNA gene sequence-based phylogenetic analysis showed that strain $\mathrm{V}^{\top}$ formed a monophyletic cluster together with $F$. cupricumulans $\mathrm{BH}^{\top}$ and all other thermophilic isolates with available $16 \mathrm{~S}$ rRNA gene sequences, whereas $F$. acidiphilum $\mathrm{Y}^{\top}$ formed another cluster with mesophilic isolates within the family Ferroplasmaceae. DNA-DNA hybridization values between strain $\mathrm{V}^{\top}$ and $F$. cupricumulans $\mathrm{BH}^{\top}$ were well below $70 \%$, indicating that the two strains belong to separate species. Principal membrane lipids of strain $\mathrm{V}^{\top}$ were dibiphytanyl-based tetraether lipids containing pentacyclic rings. The polar lipids were dominated by a single phosphoglycolipid derivative based on a galactosyl dibiphytanyl phosphoglycerol tetraether, together with smaller amounts of monoglycosyl and diglycosyl dibiphytanyl ether lipids and the corresponding phosphoglycerol derivatives. The major respiratory quinones present were naphthoquinone derivatives. Given the notable physiological and chemical differences as well as the distinct phylogenetic placement of the new isolate relative to the type species of the genus Ferroplasma, we propose strain $\mathrm{V}^{\top}$ as a member of a new genus and species, Acidiplasma aeolicum gen. nov., 
sp. nov. The type strain of Acidiplasma aeolicum is strain $\mathrm{V}^{\top}\left(=\mathrm{DSM} 18409^{\top}=\mathrm{JCM} 14615^{\top}\right)$. In addition, we propose to transfer Ferroplasma cupricumulans Hawkes et al. 2008 to the genus Acidiplasma as Acidiplasma cupricumulans comb. nov. (type strain $\mathrm{BH}^{\top}=\mathrm{DSM} 16551^{\top}=\mathrm{JCM}$ $\left.13668^{\top}\right)$.

Members of the family Ferroplasmaceae inhabit a number of acidic environments in diverse geographical locations (Golyshina \& Timmis, 2005) with stable, low $\mathrm{pH}$, moderate temperatures and high concentrations of iron, e.g. sulfide ores, mining wastewaters and acidic pools. The family Ferroplasmaceae is one of the three families of the order Thermoplasmatales. Members of this order are the most acidophilic microbes known to date. Thermoplasma acidophilum (from a self-heating coal pile; Darland et al., 1970) and Thermoplasma volcanium (isolated from submarine and continental solfataras on Vulcano Island; Segerer et al., 1988), Picrophilus torridus and Picrophilus oshimae (Schleper et al., 1995, 1996), Ferroplasma acidiphilum and Ferroplasma cupricumulans (Golyshina et al., 2000; Hawkes et al., 2006, 2008) and the recently described Thermogymnomonas acidicola (Itoh et al., 2007) constitute the described species of the order Thermoplasmatales with validly published names. Based on $16 \mathrm{~S}$ rRNA gene sequence data, the order Thermoplasmatales constitutes an isolated cluster, which branches in most phylogeny calculations between the Methanobacteriales and the Methanomicrobiales/halophiles (Huber \& Stetter, 2006).

In the present work, we describe the isolation and characterization of a novel acidophilic archaeon from the order Thermoplasmatales, family Ferroplasmaceae, strain $\mathrm{V}^{\mathrm{T}}$, that belongs to a new genus and species, Acidiplasma aeolicum gen. nov., sp. nov., and comparison of this isolate with the type strain of Ferroplasma cupricumulans (Hawkes et al., 2006), which we propose to transfer to the genus Acidiplasma as Acidiplasma cupricumulans comb. nov.

Water and sediment samples from a hydrothermal pool near Porto di Levante on Vulcano Island, in the Aeolian archipelago near Sicily, Italy, were taken on 30 April 2005 using sterile $50 \mathrm{ml}$ Falcon tubes and transported to the laboratory at ambient temperature. The $\mathrm{pH}$ of the aqueous phase was measured on-site to be 2.0; the content of $\mathrm{Fe}^{2+}$ was $25-50 \mathrm{mg} \mathrm{l}^{-1}$. Incorporations of sulfur in sand and gravel were visible, and the temperature on-site at the time of sampling was $25{ }^{\circ} \mathrm{C}$. Samples of water-saturated volcanic sand/gravel were used as inocula $(5 \%, \mathrm{v} / \mathrm{v})$ in medium $9 \mathrm{~K}$, $\mathrm{pH} 1.7$, supplemented with $0.02 \%$ yeast extract, in 0.51 Erlenmeyer flasks with trace element solution (SL-10), as reported elsewhere (Golyshina et al., 2000). The medium was additionally amended with potassium tetrathionate at concentrations of $0.5-20 \mathrm{mM}$. The flasks were incubated with agitation (120 r.p.m.) at temperatures of 30, 40 and $50{ }^{\circ} \mathrm{C}$. Later, serial dilutions of enrichment cultures were carried out to isolate pure cultures of the micro-organisms. Culture purity was controlled by phase-contrast microscopy and by PCR where the major criteria were (i) the inability to obtain any bacterial PCR amplicons with standard oligonucleotide pairs (F27-R518 and F530R1492) and (ii) the homogeneity of sequences of PCR amplicons obtained using Archaea-specific primers (oligonucleotide sequences given below). The culture containing the isolate designated ' $\mathrm{V}$ ' was selected for further investigations. To estimate the optimal growth parameters, the culture was incubated at $0-70{ }^{\circ} \mathrm{C}$ and $\mathrm{pH} 0-5$.

F. cupricumulans $\mathrm{BH} 2^{\mathrm{T}}$ was cultured under the conditions recommended in the primary isolation/description report by Hawkes et al. (2006).

Exponentially grown cells were fixed with $1 \%$ glutardialdehyde in growth medium at $4{ }^{\circ} \mathrm{C}$ for 14 days. Fixed cells were adsorbed to poly-L-lysine-treated Formvar carbon foils for $15 \mathrm{~min}$ at ambient temperature, which were then washed with water for $3 \mathrm{~s}$, blotted with filter paper and airdried. Samples were shadow-cast with $\mathrm{Pt} / \mathrm{C}$ as described previously (Golyshina et al., 2000). After initial fixation, cells were additionally fixed at a final concentration of $2 \%$ glutardialdehyde in $100 \mathrm{mM}$ cacodylate, $\mathrm{pH}$ 7.2. Cells were post-fixed with $1 \% \mathrm{OsO}_{4} / 100 \mathrm{mM}$ cacodylate, $\mathrm{pH} 7.2$, for $90 \mathrm{~min}$ at ambient temperature, washed once for $2 \mathrm{~min}$ in $100 \mathrm{mM}$ cacodylate, $\mathrm{pH} \mathrm{7.2,} \mathrm{and} \mathrm{dehydrated} \mathrm{in} \mathrm{an}$ ascending ethanol series before being embedded. The $70 \%$ ethanol phase was supplemented with $1 \%$ uranyl acetate. Cells were finally embedded in epoxy resin (Spurr, 1969). Energy-filtered transmission electron microscopy of ultrathin sections and shadow-cast samples was carried out according to Lünsdorf et al. (2001).

A general impression of the overall shape of cells of strain $\mathrm{V}^{\mathrm{T}}$ and F. cupricumulans $\mathrm{BH} 2^{\mathrm{T}}$ could be obtained from shadow-cast preparation by transmission electron microscopy (Figs 1a and 2a). Strain $\mathrm{V}^{\mathrm{T}}$ appeared to form compact pleomorphic to coccoid cells (Fig. 1a) with a tendency towards subsphericalization of the cell body under the growth conditions used (Fig. 1a; open arrowheads). Corresponding ultrathin sections of cells showed cytoplasmic voids (Fig. 1b; asterisks). Cells were delineated by a unique cytoplasmic membrane [Figs $1 \mathrm{~b}$ and $2 \mathrm{~b} ; \mathrm{cm}$ (inset)] and no additional surface-coating matrix could be observed. Occasionally elongated, pleomorphic cells could be observed (Fig. 1a, b; p), but selenomorphic cells were also present (Fig. 1a, b; single arrows). Cells were nonmotile; mycoplasma-like gliding motility has not been observed by phase-contrast microscopy. A further morphological feature of strain $\mathrm{V}^{\mathrm{T}}$, which could not be observed for F. cupricumulans $\mathrm{BH} 2^{\mathrm{T}}$, was the presence of filamentous protrusions extending from the cell surface [Fig. 1a, b (inset); twin-arrows]. 


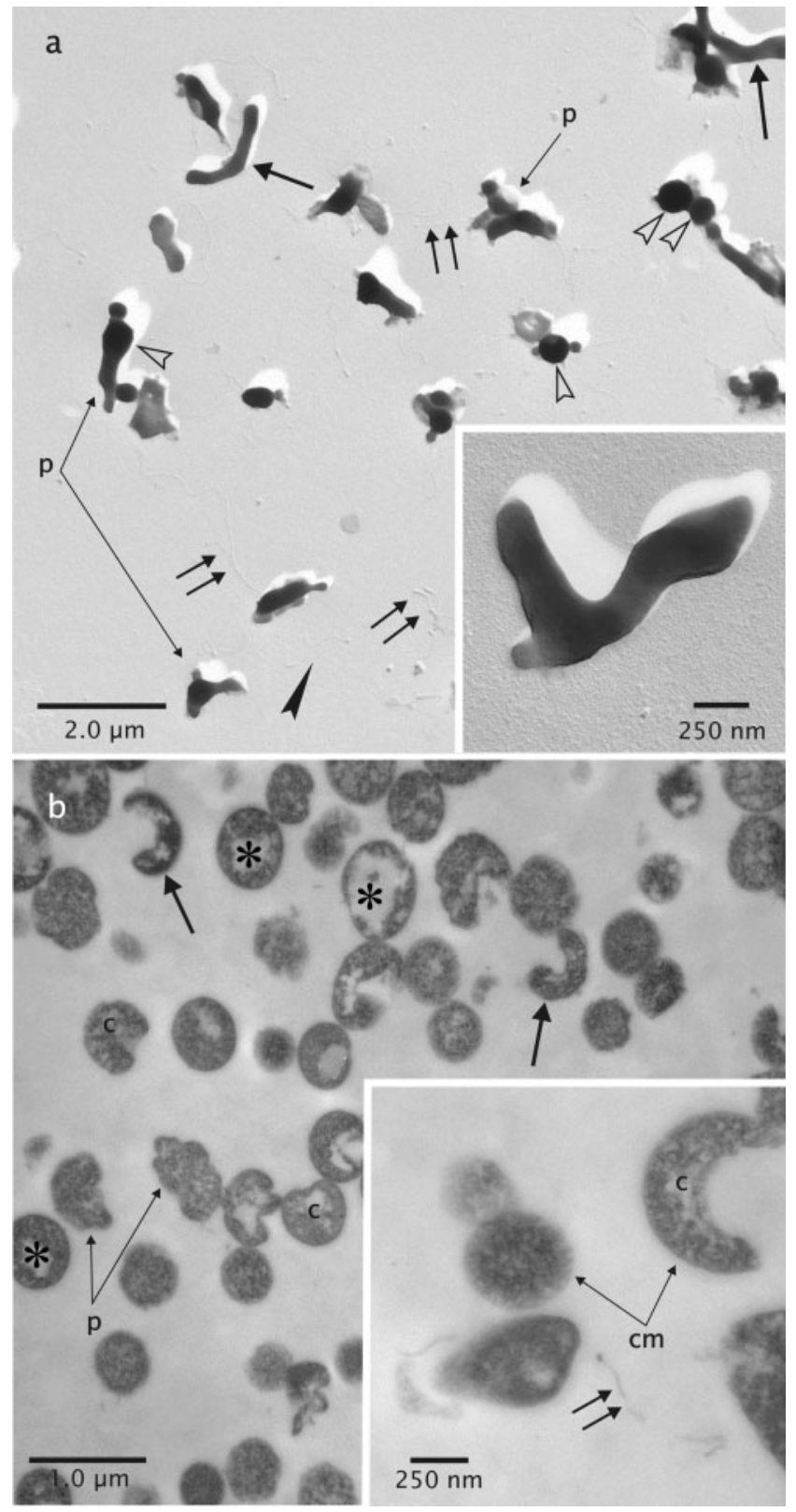

Fig. 1. Ultrastructure of strain $V^{\top}$ after shadow-casting (a) and ultrathin-sectioning (b). Selenomorphic cells (single arrows) are a characteristic feature, but cells generally appear pleomorphic (p). Subsphericulization (open arrowheads) is typically recognized, possibly based on the formation of intracellular voids (asterisks). The inset in (b) shows detailed features of typical cell morphology; the cytoplasmic membrane is indicated $(\mathrm{cm})$. Double arrows indicate filamentous protrusions. The large arrowhead in (a) indicates the shadowing direction. $\mathrm{C}$, Chromosome.

Cells of F. cupricumulans $\mathrm{BH} 2^{\mathrm{T}}$ appeared rather rod-like and tended to branch (Fig. 2a; double arrowheads and inset). Similarly to strain $\mathrm{V}^{\mathrm{T}}$, these cells contained electrontranslucent intracellular voids (Fig. 2b; asterisks), which

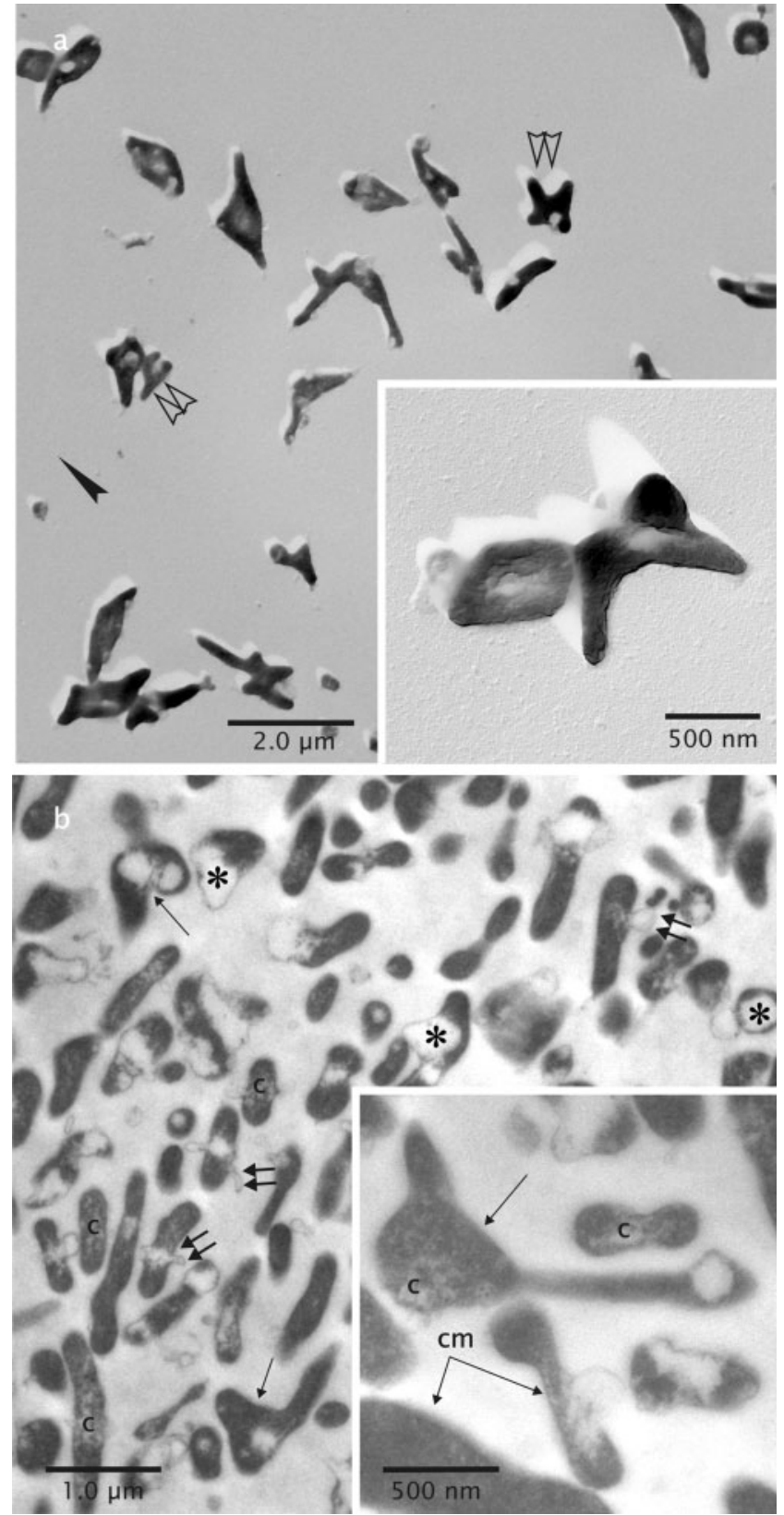

Fig. 2. Shadow-cast (a) and ultrathin-sectioned (b) samples of $F$. cupricumulans $\mathrm{BH} 2^{\top}$. See legend to Fig. 1 for further details. Double arrowheads indicate branched cells.

often tended to form extrusions (Fig. 2b; double arrows), and could finally form vesicles.

Growth was monitored by determination of the protein content of the culture using the Bio-Rad protein assay kit. Concentrations of $\mathrm{Fe}^{2+}$ were estimated using Merckoquant paper test strips (Merck). Pure cultures of strain $\mathrm{V}^{\mathrm{T}}$ were grown routinely in $500 \mathrm{ml}$ Erlenmeyer flasks on a rotary shaker ( 150 r.p.m.) at $42-45{ }^{\circ} \mathrm{C}$ containing $100 \mathrm{ml}$ medium $9 \mathrm{~K}$ with $\mathrm{FeSO}_{4} \cdot 7 \mathrm{H}_{2} \mathrm{O}\left(25 \mathrm{~g} \mathrm{l}^{-1}\right)$ and trace element 
solution SL-10 (Golyshina et al., 2000) or AB medium (Segerer et al., 1988) supplemented with yeast extract $(0.1 \%, \mathrm{w} / \mathrm{v})$ and glucose $(0.1-1 \%)$.

The optimal conditions for growth of strain $\mathrm{V}^{\mathrm{T}}$ (see the growth curve in Supplementary Fig. S1, available in IJSEM Online) were in the ferrous iron-containing medium $9 \mathrm{~K}$ supplemented with yeast extract $(0.02 \% \mathrm{w} / \mathrm{v})$ with the addition of potassium tetrathionate (in the range 0.5$20 \mathrm{mM}$; best growth at $2-5 \mathrm{mM}$ ). The specific growth rate under these conditions was $0.032 \mathrm{~h}^{-1}$. Strain $\mathrm{V}^{\mathrm{T}}$ grew in the temperature range $15-65{ }^{\circ} \mathrm{C}$, with an optimum at $42-$ $45^{\circ} \mathrm{C}$, and at $\mathrm{pH} 0-4$, with an optimum at $\mathrm{pH}$ 1.4-1.6. Strain $\mathrm{V}^{\mathrm{T}}$ also grew reasonably well chemo-organotrophically (albeit slower, with the specific growth rate no higher than $0.02 \mathrm{~h}^{-1}$ ) without addition of ferrous iron: on yeast extract alone, at $0.002-1 \%(\mathrm{w} / \mathrm{v})$, and on yeast extract and $0.1-1 \%$ glucose in modified Allen medium (AB) (Segerer et al., 1988).

Strain $\mathrm{V}^{\mathrm{T}}$ exhibited no growth on elemental sulfur in $\mathrm{AB}$ medium. Growth of strain $\mathrm{V}^{\mathrm{T}}$ without potassium tetrathionate was scarce, yielding 10-fold less biomass in total, and was accompanied by a very slow oxidation of ferrous iron [360 h for full conversion of $\mathrm{Fe}(\mathrm{II})$ to $\mathrm{Fe}(\mathrm{III})$ ], which is in stark contrast to the full conversion within $72 \mathrm{~h}$ in the presence of potassium tetrathionate. However, the reduced sulfur compounds potassium tetrathionate and sodium thiosulfate alone did not support growth of strain $\mathrm{V}^{\mathrm{T}}$.

Aerobic growth on other organic substrates was determined using Biolog GN2 microplates with medium $9 \mathrm{~K}$ and $\mathrm{AB}$ medium with and without $0.02 \%$ yeast extract. Growth was estimated at $45{ }^{\circ} \mathrm{C}$ after incubation for $48 \mathrm{~h}(9 \mathrm{~K})$ and $96 \mathrm{~h}(\mathrm{AB})$. The substrates examined were as follows: sugars and related compounds: L-arabinose, fructose, sucrose, Lsorbitol, L- and D-glucose, glucose 1-phosphate, glucose 6-phosphate, maltose, D-xylose, D-mannitol, lactose, cellobiose, D-galactose, mannose, L-fucose, gentiobiose, myoinositol, D-lactulose, melibiose, methyl $\beta$-D-glucoside, Dpsicose, rhamnose, L-rhamnose, D-sorbitol, trehalose, turanose, xylitol, cyclodextrin, dextrin, inosine, uridine, thymidine and glycogen; organic acids and their salts: aminobutyric acid, methyl pyruvate, monomethyl succinate, acetic acid, cis-acetic acid, citric acid, formic acid, Dgalactonic acid lactone, D-galacturonic acid, D-gluconic acid, D-glucosaminic acid, D-glucuronic acid, $\alpha$-hydroxybutyric acid, $\beta$-hydroxybutyric acid, $\gamma$-hydroxybutyric acid, $p$-hydroxyphenylacetic acid, itaconic acid, $\alpha$-ketobutyric acid, $\alpha$-ketoglutaric acid, $\alpha$-ketovaleric acid, DL-lactic acid, malonic acid, propionic acid, quinic acid, D-saccharic acid, sebacic acid, succinic acid, bromosuccinic acid, succinamic acid, urocanic acid and L-pyroglutamic acid; amino acids: glucuronamide, alaninamide, D-alanine, L-alanyl glycine, Lasparagine, L-aspartic acid, L-glutamic acid, glycyl Laspartic acid, glycyl L-glutamic acid, L-histidine, hydroxyL-proline, L-leucine, L-ornithine, L-phenylalanine, L-proline, D-serine, D-serine, L-threonine, DL-carnitine, putrescine and phenylethylamine; alcohols: 2-aminoethanol, 2,3-butanediol, glycerol, L- $\alpha$-glycerol phosphate, adonitol, D-arabitol and i-erythritol; and others: Tweens 40 and 80, $\mathrm{N}$-acetyl D-galactosamine and $\mathrm{N}$-acetyl D-glucosamine. Strain $\mathrm{V}^{\mathrm{T}}$ was not capable of growth on any of the organic substrates included in the GN2 microplate under any conditions tested with the sole exception of utilization of glucose in the presence of yeast extract.

Anaerobic growth was assayed in closed vessels $(100 \mathrm{ml})$ with medium $9 \mathrm{~K}$ with $\mathrm{Fe}_{2}\left(\mathrm{SO}_{4}\right)_{3}$ as electron acceptor, supplemented with $0.02 \%(\mathrm{w} / \mathrm{v})$ yeast extract and potassium tetrathionate $(5 \mathrm{mM})$ as electron donor, and in $\mathrm{AB}$ medium with yeast extract $(0.02-0.1 \% \mathrm{w} / \mathrm{v})$. The medium was flushed with $\mathrm{N}_{2} / \mathrm{CO}_{2}(80: 20, \mathrm{v} / \mathrm{v})$ or pure $\mathrm{N}_{2}$ and the headspace contained the same gas mixture used for flushing. Strain $\mathrm{V}^{\mathrm{T}}$ demonstrated anaerobic growth in all cases. With only $\mathrm{N}_{2}$ present in the headspace, strain $\mathrm{V}^{\mathrm{T}}$ grew on yeast extract, suggesting it is able to perform fermentation.

Inhibition of growth of strain $\mathrm{V}^{\mathrm{T}}$ under optimal growth conditions was observed for rifampicin, chloramphenicol and tetracycline; no inhibition was observed with streptomycin, kanamycin, vancomycin, gentamicin or ampicillin (all antibiotics added at $100 \mu \mathrm{g} \mathrm{ml}^{-1}$ ).

Lipids were extracted using a standard two-stage protocol. Briefly, respiratory lipoquinones were extracted using methanol/hexane $(2: 1, \mathrm{v} / \mathrm{v})$ and extracted into the hexane phase by the addition of 1 vol. cold hexane. The methanolic aqueous phase was further re-extracted by the addition of 2 vols cold $0.3 \%$ aqueous $\mathrm{NaCl}$ followed by 2 vols cold hexane. The pooled hexane phases were combined and concentrated to a small volume under a stream of nitrogen. After separation by TLC into lipoquinone classes (e.g. naphthoquinones, benzoquinones), the respiratory lipoquinone composition of each class was determined by HPLC, using an $\mathrm{RP}_{18}$ column and heptane/methanol (1:9, $\mathrm{v} / \mathrm{v})$ as a solvent.

Polar lipids were further extracted from the cell debris and the aqueous methanolic phase by bringing the solvent to a final chloroform/methanol $/ 0.3 \% \mathrm{NaCl}$ ratio of $1: 2: 0.8$ (by vol.). Cell debris was removed by centrifugation and lipids were extracted from the supernatant into chloroform by the addition of chloroform and aqueous $0.3 \% \mathrm{NaCl}$ to give a final chloroform/methanol/ $0.3 \% \mathrm{NaCl}$ ratio of $1: 1: 0.9$ (by vol.). Polar lipids were dried under a stream of nitrogen and redissolved in a small volume of chloroform/ methanol $(2: 1, \mathrm{v} / \mathrm{v})$. Polar lipids were separated on silica gel thin layers (Fig. 3) using the solvent systems chloroform/methanol/water $(65: 25: 4$, by vol.) in the first dimension and chloroform/methanol/acetic acid/water $(80: 12: 15: 4$, by vol.) in the second dimension. Total lipids were visualized using $5 \%$ molybdatophosphoric acid in ethanol. Functional groups were detected with Zinzadze reagent (phosphate), $\alpha$-naphthol/sulfuric acid (sugars), ninhydrin (free amino groups) and periodate-Schiff (vicinal hydroxyl groups). 


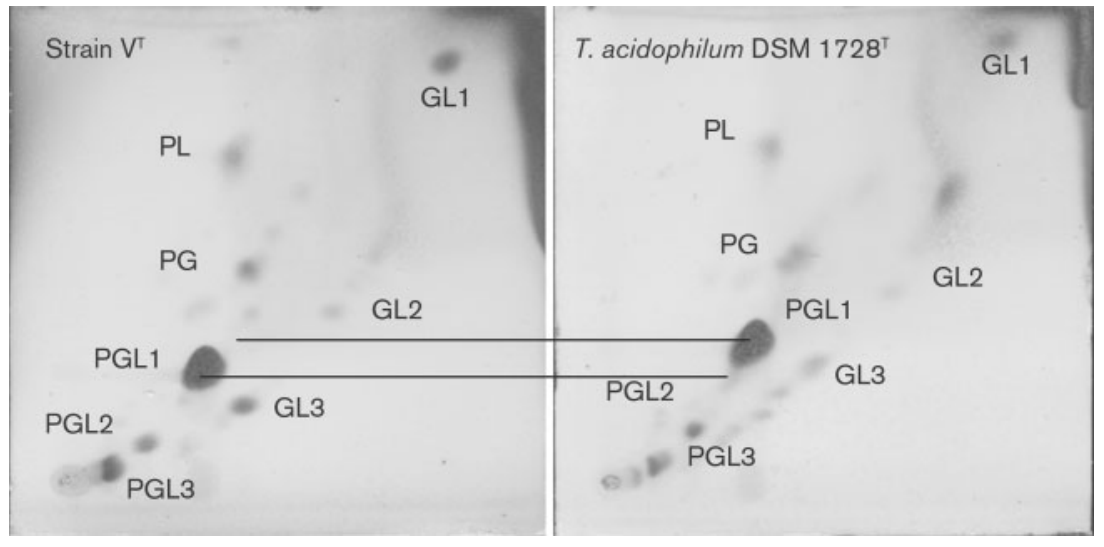

Fig. 3. Two-dimensional TLC of polar lipids of strain $\mathrm{V}^{\top}$ and Thermoplasma acidophilum DSM $1728^{\top}$. The solvent system is detailed in the text. PL, Phospholipid (probably phosphatidic acid); PG, phosphatidylglycerol; PGL1, glycosyl-dibiphytanyl-phosphoglycerol; PGL2 and PGL3, phosphoglygolipids (respectively containing two and three sugar residues); GL1, GL2 and GL3, glycolipids (respectively containing one, two and three sugar residues).

MALDI MS was carried out on lipids isolated from unsprayed TLC plates that had been eluted from the silica, on a Bruker Ultraflex instrument (Bruker-Daltonics) using a matrix of $\alpha$-cyano-4-hydroxycinnamic acid. For MS-MS analyses, selected parent ions were subjected to laserinduced dissociation (LID) and the resulting fragment ions were separated by the second TOF stage (LIFT) of the instrument. Carbohydrate compositional analyses were performed according to Chaplin (1982). The carbohydrate moiety in the major glycosyl dibiphytanyl phosphoglycerol lipid of strain $\mathrm{V}^{\mathrm{T}}$ was different from those of representatives of the genera Thermoplasma, Picrophilus and Ferroplasma reported previously (Schleper et al., 1996; Swain et al., 1997; Batrakov et al., 2002) (see below for more details).

The $\mathrm{G}+\mathrm{C}$ content of the genomic DNA was $36 \mathrm{~mol} \%$, as determined directly by HPLC with a Zorbax Eclipse XDBC8 column (Agilent), with purified, non-methylated lambda phage DNA (Sigma) used as a control, according to methods described previously (Mesbah et al., 1989; Tamaoka \& Komagata, 1984).

To determine the $16 \mathrm{~S}$ rRNA gene sequence, total DNA was isolated from a late-exponential phase culture by using the GNOME DNA kit (Qbiogene). The 16S rRNA gene was amplified by PCR using the forward primers A23F (5' TCYGGTTGATCCTGCC-3') and F530 (5'-TCCGTGCCAGCAGCCGCCG-3') and the reverse primer R1492 (5'-CGGYTACCTTGTTACGACTT-3'). Amplification was done in $50 \mu$ reaction volumes with Taq DNA polymerase (Invitrogen) and original reagents according to the basic PCR protocol. The amount of template DNA used was approximately $0.5 \mathrm{ng}$. The reaction ran for 30 cycles, each of $96{ }^{\circ} \mathrm{C}$ for $1 \mathrm{~min}, 45{ }^{\circ} \mathrm{C}$ for $1 \mathrm{~min}$ and $72{ }^{\circ} \mathrm{C}$ for $2 \mathrm{~min}$, with a final extension at $72{ }^{\circ} \mathrm{C}$ for $10 \mathrm{~min}$. Sequencing of the gel-purified PCR product was performed with the above oligonucleotides according to the protocol for the BigDye Terminator v1.1 cycle sequencing kit (Applied Biosystems). The GenBank NR database was searched for similar sequences using the online BLASTN program (Altschul et al., 1997). Phylogenetic and molecular evolutionary analyses were conducted using multiple alignment CLUSTAL w software at the EBI website (http:// www.ebi.ac.uk) together with the phylogeny analysis software MEGA version 3.1 (Kumar et al., 2004). The latter was used for phylogenetic distance calculations and tree construction (neighbour-joining method, Jukes-Cantor model, with the sampling of 1000 tree replicates for bootstrap calculations).

The 16S rRNA gene sequence of strain $\mathrm{V}^{\mathrm{T}}$ was observed to cluster within the family Ferroplasmaceae, with 95.4\% sequence identity to $F$. acidiphilum $\mathrm{Y}^{\mathrm{T}}$ and $100 \%$ sequence identity to F. cupricumulans $\mathrm{BH} 2^{\mathrm{T}}$.

DNA-DNA hybridization of strain $\mathrm{V}^{\mathrm{T}}$ with F. cupricumulans $\mathrm{BH} 2^{\mathrm{T}}$ was performed by the DSMZ Identification Service. Total DNA was isolated using a French pressure cell (Thermo Spectronic) from $3 \mathrm{~g}$ wet cell mass suspended in 2-propanol/water $(1: 1, \mathrm{v} / \mathrm{v})$ and purified by chromatography on hydroxyapatite as described by Cashion et al. (1977). DNA-DNA hybridization was carried out as described by De Ley et al. (1970) with the modifications described by Huß et al. (1983) using a Cary 100 Bio UV/Vis spectrophotometer equipped with a Peltier-thermostatted $6 \times 6$ multicell changer and a temperature controller with in situ temperature probe (Varian). The analysis showed the level of DNA-DNA hybridization in $2 \times$ SSC at $61{ }^{\circ} \mathrm{C}$ to be 46.4 and $53.1 \%$ in two independent measurements, indicating that the strains tested do not belong to the same species according to the recommendations of Wayne et al. (1987).

16S rRNA gene sequence analysis of strain $\mathrm{V}^{\mathrm{T}}$ revealed its affiliation with $F$. cupricumulans $\mathrm{BH} 2^{\mathrm{T}}$ (100\% $16 \mathrm{~S}$ rRNA gene sequence identity) and its next-closest relatives to be F. acidiphilum $\mathrm{Y}^{\mathrm{T}}$, Picrophilus torridus DSM $9790^{\mathrm{T}}$ and $P$. oshimae DSM $9789^{\mathrm{T}}$, with 95.4, 94 and $92 \% 16 \mathrm{~S}$ rRNA gene sequence identity, respectively (Fig. 4). The study of the physiology of strain $\mathrm{V}^{\mathrm{T}}$ has indicated a number of features that are typical of members of the order Thermoplasmatales (acidophily, yeast extract requirement, aerobic and anaerobic lifestyles and ferrous iron as the substrate, which is, in particular, common to representatives of the family Ferroplasmaceae), but also showed a 


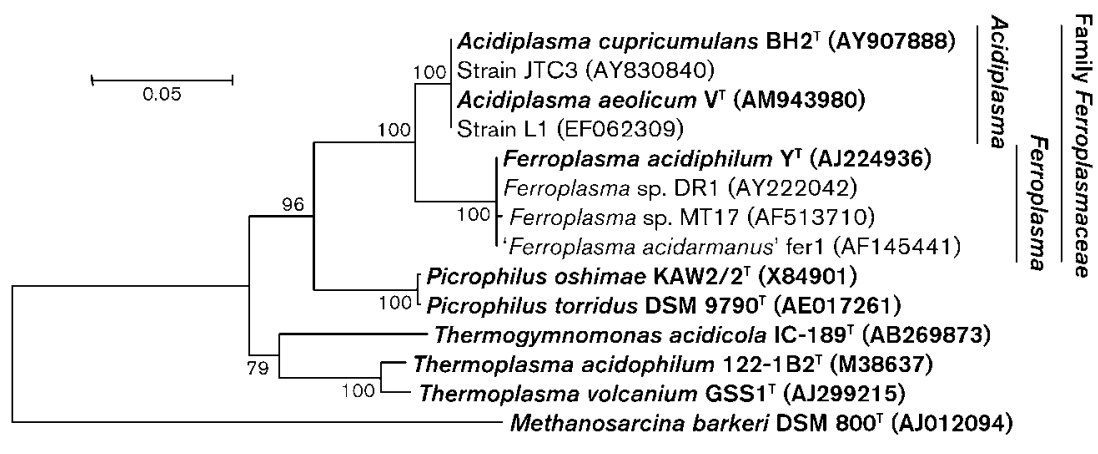

Fig. 4. Neighbour-joining phylogenetic tree based on 16S rRNA gene sequences, showing the position of strain $\mathrm{V}^{\top}$ within the order Thermoplasmatales. Organisms with validly published names are indicated in bold. GenBank accession numbers are given in parentheses. Two distinct monophyletic clusters, one including thermophilic isolates (strain $\mathrm{V}^{\top}, \mathrm{BH} 2^{\top}, \mathrm{JTC} 3$ and L1) and another comprising mesophilic isolates ( $F$. acidiphilum $\mathrm{Y}^{\top}$, DR1, fer1 and MT17), are well separated. The sequence of Methanosarcina barkeri DSM $800^{\top}$ was used as the outgroup. Bar, 0.05 substitutions per nucleotide position. number of distinct features (Table 1). The optimal temperature for growth of strain $\mathrm{V}^{\mathrm{T}}\left(42-45^{\circ} \mathrm{C}\right)$ is higher than that of $F$. acidiphilum $\mathrm{Y}^{\mathrm{T}}\left(35^{\circ} \mathrm{C}\right)$ and is within the lower growth temperature limit for thermophiles. Furthermore, the phylogenetic analysis affiliated strain $\mathrm{V}^{\mathrm{T}}$ with the archaeon $F$. cupricumulans $\mathrm{BH}_{2}{ }^{\mathrm{T}}$ and all other thermophilic isolates for which 16S rRNA gene sequences are available in GenBank (JTC3 and L1) and which form a separate cluster within the family Ferroplasmaceae (Fig. 4). In contrast, the type strain of the type species of Ferroplasma, F. acidiphilum $\mathrm{Y}^{\mathrm{T}}$, clusters with the mesophilic isolates DR1, fer1 and MT17 (Edwards et al., 2000; Dopson et al., 2004; Golyshina \& Timmis, 2005). Physiologically and phylogenetically, these organisms, representing a cluster of thermophiles within the family Ferroplasmaceae, occupy an interim position between the common, mesophilic members of the family Ferroplasmaceae and the thermophiles of the family Picrophilaceae.

The upper temperature limit for growth of strain $\mathrm{V}^{\mathrm{T}}$ (about $65{ }^{\circ} \mathrm{C}$ ) was close to that of moderately thermophilic members of the genera Thermoplasma and Picrophilus, but the optimum is closer to all known Ferroplasma-related strains. The isolate was able to grow over relatively wide ranges of temperature $\left(15-65^{\circ} \mathrm{C}\right)$ and $\mathrm{pH}(0-4)$. Such a broad tolerance suggests that the organism is well adapted to environmental changes and might reflect temperature/ $\mathrm{pH}$ fluctuations at its isolation site.

We also performed MALDI-TOF analysis of the proteome of strain $\mathrm{V}^{\mathrm{T}}$. Unlike $F$. acidiphilum $\mathrm{Y}^{\mathrm{T}}$, whose proteins have always shown the best hits to those from the 'Ferroplasma acidarmanus' in silico proteome (Ferrer et al., 2007), the majority of over 450 individual proteins resolved from strain $\mathrm{V}^{\mathrm{T}}$ were not affiliated, according to peptide fragment masses, to any organism with a sequenced genome, with only a small fraction $(<15 \%)$ giving best hits to proteins from Picrophilus torridus (O. V. Golyshina, M. Ferrer, A. Beloqui and P. N. Golyshin, unpublished). These data further emphasize the low similarity in individual protein sequences of $F$. acidiphilum $\mathrm{Y}^{\mathrm{T}}$ and strain $\mathrm{V}^{\mathrm{T}}$ and point to very different genomic backgrounds.

Strain $\mathrm{V}^{\mathrm{T}}$ is the first organism among the known members of the family Ferroplasmaceae able to grow chemoorganotrophically on yeast extract or a mixture of yeast extract and glucose, producing a significant amount of

Table 1. Growth conditions and DNA G+C contents of organisms from the family Ferroplasmaceae and representatives of other known genera of the order Thermoplasmatales

Taxa: 1, F. acidiphilum $\mathrm{Y}^{\mathrm{T}}$ (data from Golyshina et al., 2000); 2, F. cupricumulans BH2 ${ }^{\mathrm{T}}$ (Hawkes et al., 2006); 3, strain $\mathrm{V}^{\mathrm{T}}$ (this study); 4, Picrophilus (Schleper et al., 1995); 5, Thermoplasma (Darland et al., 1970; Huber \& Stetter, 2006); 6, Thermogymnomonas (Itoh et al., 2007).

\begin{tabular}{|c|c|c|c|c|c|c|}
\hline Characteristic & 1 & 2 & 3 & 4 & 5 & 6 \\
\hline Anaerobic growth & - & + & + & - & + & - \\
\hline $\mathrm{Fe}^{2+}$ oxidation & + & + & + & - & - & - \\
\hline Chemo-organotrophic growth & - & - & + & + & + & + \\
\hline \multicolumn{7}{|l|}{ Growth temperature $\left({ }^{\circ} \mathrm{C}\right)$} \\
\hline Range & $15-45$ & $22-63$ & $15-65$ & $47-65$ & $33-67$ & $38-68$ \\
\hline Optimum & 35 & 53.6 & 45 & 60 & 59 & 60 \\
\hline \multicolumn{7}{|l|}{$\mathrm{pH}$ for growth } \\
\hline Range & $1.3-2.2$ & $0.4-1.8$ & $0-4$ & $0-3.5$ & $0.5-4.0$ & $1.8-4$ \\
\hline Optimum & 1.7 & $1-1.2$ & $1.4-1.6$ & 0.7 & $1-2$ & 3.0 \\
\hline DNA G $+\mathrm{C}$ content $(\mathrm{mol} \%)$ & 37 & 34 & 36 & 36 & $38-46$ & 56 \\
\hline
\end{tabular}


biomass (more than $100 \mathrm{mg}$ protein $\mathrm{l}^{-1}$ ), with maximal values after prolonged periods of time. Other simple organic substrates were not utilized by this organism. All known organisms belonging to the order Thermoplasmatales have an absolute requirement for yeast extract for growth (Darland et al., 1970; Schleper et al., 1995, 1996; Golyshina et al., 2000; Dopson et al., 2004; Hawkes et al., 2006; Itoh et al., 2007).

Despite sharing $100 \% 16 \mathrm{~S}$ rRNA gene sequence identity, strain $\mathrm{V}^{\mathrm{T}}$ and $F$. cupricumulans $\mathrm{BH}^{\mathrm{T}}$, isolated from an industrial mineral sulfide bioleaching heap in Monywa, Burma (Hawkes et al., 2006), do not belong to the same species on the basis of DNA-DNA hybridization results.

Morphological differences between strain $\mathrm{V}^{\mathrm{T}}$ and $F$. cupricumulans $\mathrm{BH} 2^{\mathrm{T}}$ were relatively clear: strain $\mathrm{V}^{\mathrm{T}}$ forms pleomorphic to coccoid cells, while cells of $F$. cupricumulans $\mathrm{BH} 2^{\mathrm{T}}$ were characterized by rod-like forms with a tendency towards branched morphologies. A further morphological feature of strain $\mathrm{V}^{\mathrm{T}}$, distinct from $F$. cupricumulans $\mathrm{BH} 2^{\mathrm{T}}$, is the presence of filamentous protrusions extending from the cell surface.

The major polar lipids present were compared with lipids extracted from Thermoplasma acidophilum DSM $1728^{\mathrm{T}}$. The major glycophospholipids present in strain $\mathrm{V}^{\mathrm{T}}$ and Thermoplasma acidophilum DSM $1728^{\mathrm{T}}$ had slightly different $R_{\mathrm{f}}$ values, indicating differences that probably result from differences in sugar components. Both compounds were rapidly periodate-Schiff-positive, indicating the liberation of formaldehyde and the presence of (at least) two adjacent hydroxyl groups, with one in a chainterminal position. The $R_{\mathrm{f}}$ values of the glycolipids were consistent with those of mono-, di- and triglycosyl lipids. The $R_{\mathrm{f}}$ values of the major phospholipids, which were also rapidly periodate-Schiff-positive, were consistent with their identification as a phosphoglycerol derivatives of the corresponding mono-, di- and triglycosyl glycolipids.

The most abundant phosphoglycolipid spot of strain $\mathrm{V}^{\mathrm{T}}$ yielded a series of molecular ions exhibiting mass increments of $2 \mathrm{Da}$ starting at $\mathrm{m} / z 1632.3$ and ending at $1640.3[\mathrm{M}+\mathrm{Na}]^{+}$plus an analogous pattern $22 \mathrm{Da}$ upmass $[\mathrm{M}-\mathrm{H}+2 \mathrm{Na}]^{+}$, suggesting the presence of dibiphytanyl phosphoglycerol tetraether compounds differing in the number (0-4) of cyclopentyl rings, with one free glycerol hydroxyl group linked to a hexose residue and the other via a phosphodiester linkage to another glycerol residue. Comparison of the glycophospholipid of strain $\mathrm{V}^{\mathrm{T}}$ with the analogous structure isolated from Thermoplasma acidophilum DSM $1728^{\mathrm{T}}$ revealed clear differences in the pattern of cyclopentyl rings and indicated, on average, more cyclopentyl rings in the former organism. LID experiments yielded fragment ions that confirmed the presence of a dibiphytanyl phosphoglycerol tetraether basic structure modified by a phophatidylglycerol residue linked to one free hydroxyl group and a hexose residue linked to the other. The identity of this hexose residue in the major lipid from both strains was determined by GC/MS after methanolysis followed by trimethylsilylation. Whereas gulose was identified in the lipid from Thermoplasma acidophilum DSM $1728^{\mathrm{T}}$, galactose was found in the analogous compound from strain $\mathrm{V}^{\mathrm{T}}$, clearly demonstrating the differences between the two strains.

NMR analysis of the major polar lipid from Thermoplasma acidophilum DSM $1728^{\mathrm{T}}$ was consistent with the results reported by Swain et al. (1997). NMR analysis of PGL1 (Fig. 3) of strain $\mathrm{V}^{\mathrm{T}}$ showed that the sugar present is $\beta$ galactopyranose, consistent with the finding of galactopyranose after hydrolysis of the lipid. No evidence was found for the presence of points of unsaturation of the isoprenoid side chain. Full details will be reported elsewhere.

The predominant respiratory lipoquinones present were naphthoquinones that were present in two distinct bands. They did not co-elute on an $\mathrm{RP}_{18}$ column with authentic MK-7, MMK-7 (thermoplasma quinone 7) or MTK-7 (menathioquinone-7), which have been reported previously for members of this order investigated to date (Collins, 1985; Shimada et al., 2001).

Based on other reported data, it is interesting to note that members of the genus Thermoplasma have $\beta$-L-gulose in this lipid (Swain et al., 1997), whereas members of the genera Picrophilus and Ferroplasma are reported to have $\beta$-D-glucose in their major glycosyl dibiphytanyl phosphoglycerol lipid. These differences also correlate with the groupings found by $16 \mathrm{~S}$ rRNA gene sequence analysis, and one may consider them to have both evolutionary and taxonomic significance.

On the basis of 16S rRNA gene sequence comparison (95.4\% sequence identity with $F$. acidiphilum $\mathrm{Y}^{\mathrm{T}}$ and its clustering into a very distinct lineage with zero sequence mismatches) and physiological (in particular, its thermophilic nature) and chemical (the difference in sugar components in its major glycosyl dibiphytanyl phosphoglycerol lipids) characteristics and, finally, the lack of similarity in peptide fragment masses in the whole-cell proteome, which suggests a stark difference at the genomic level, strain $\mathrm{V}^{\mathrm{T}}$ is proposed to represent a new genus and species, Acidiplasma aeolicum gen. nov., sp. nov., within the family Ferroplasmaceae. Furthermore, the genus Acidiplasma is herewith proposed to accommodate another species, Acidiplasma cupricumulans comb. nov., represented by strain $\mathrm{BH}^{\mathrm{T}}$, previously described as Ferroplasma cupricumulans Hawkes et al. 2008.

\section{Description of Acidiplasma gen. nov.}

Acidiplasma (A.ci.di.plas'ma. N.L. neut. n acidum an acid; Gr. neut. n. plasma something shaped or moulded; N.L. neut. n. Acidiplasma an acid-living form).

Cells are irregular cocci, varying from spherical to filamentous. Facultatively anaerobic. Acidophilic. Moderately thermophilic. Oxidize ferrous iron in the presence of trace amounts of yeast extract. 16S rRNA gene sequences group within the family Ferroplasmaceae, in the 
order Thermoplasmatales, phylum Euryarchaeota. Known habitats are hydrothermal pools and chalcocite-containing sulfide ores. The type species is Acidiplasma aeolicum.

\section{Description of Acidiplasma aeolicum sp. nov.}

Acidiplasma aeolicum (ae.o'li.cum. L. neut. adj. aeolicum from the Aeolian archipelago, to which Vulcano Island belongs, where the type strain was isolated).

Displays the following properties in addition to those described for the genus. Exhibits filamentous protrusions extending from the cell surface. Temperature and $\mathrm{pH}$ ranges for growth are $15-65{ }^{\circ} \mathrm{C}$ (optimum $42-45{ }^{\circ} \mathrm{C}$ ) and $\mathrm{pH}$ 0-4 (optimum $\mathrm{pH}$ 1.4-1.6). Oxidizes reduced sulfur species. Able to grow organoheterotrophically with yeast extract and glucose. The $\mathrm{G}+\mathrm{C}$ content of DNA of the type strain is $36 \mathrm{~mol} \%$. Principal membrane lipids are dibiphytanyl-based tetraether lipids. The polar lipids are dominated by a single phosphoglycolipid derivative based on a galactosyl dibiphytanyl phosphoglycerol tetraether, together with smaller amounts of mono- and diglycosyl dibiphytanyl ether lipids and the corresponding phosphoglycerol derivatives. The major respiratory quinones present are naphthoquinone derivatives.

The type strain is strain $\mathrm{V}^{\mathrm{T}}\left(=\mathrm{DSM} 18409^{\mathrm{T}}=\mathrm{JCM}\right.$ $14615^{\mathrm{T}}$ ), which was isolated from a hydrothermal pool on Vulcano Island, Italy.

\section{Description of Acidiplasma cupricumulans (Hawkes et al. 2008) comb. nov.}

Acidiplasma cupricumulans (cu.pri.cu'mu.lans. L. neut. n. cuprum copper; L. part. adj. cumulans heaping up, accumulating; N.L. part. adj. cupricumulans copperaccumulating).

Basonym: Ferroplasma cupricumulans Hawkes et al. 2008.

The description is the same as that given for Ferroplasma cupricumulans by Hawkes et al. (2006). Morphology is as described for the genus; in addition, cells are often rod-like, with a tendency to form branched morphologies. The type strain is strain $\mathrm{BH} 2^{\mathrm{T}}\left(=\mathrm{DSM} 16551^{\mathrm{T}}=\mathrm{JCM} 13668^{\mathrm{T}}\right)$.

\section{Acknowledgements}

We thank Peter Franzmann for providing strain $\mathrm{BH} 2^{\mathrm{T}}$. We are grateful to Agnes Waliczek and Angelika Arnscheidt for their excellent technical assistance and to Maria Genovese for taking the samples from Vulcano Island. The work of O. V. G. was supported through the MetaGenoMik initiative (BMBF Project 0313751K). K. N. T. acknowledges the Fonds der Chemischen Industrie for generous support.

\section{References}

Altschul, S. F., Madden, T. L., Schäffer, A. A., Zhang, J., Zhang, Z., Miller, W. \& Lipman, D. J. (1997). Gapped BLAST and PSI-BLAST: a new generation of protein database search programs. Nucleic Acids Res 25, 3389-3402.
Batrakov, S. G., Pivovarova, T. A., Esipov, S. E., Sheichenko, V. I. \& Karavaiko, G. I. (2002). Beta-D-glucopyranosyl caldarchaetidylglycerol is the main lipid of the acidophilic, mesophilic, ferrous iron-oxidising archaeon Ferroplasma acidiphilum. Biochim Biophys Acta 1581, 29-35.

Cashion, P., Holder-Franklin, M. A., McCully, J. \& Franklin, M. (1977). A rapid method for the base ratio determination of bacterial DNA. Anal Biochem 81, 461-466.

Chaplin, M. F. (1982). A rapid and sensitive method for the analysis of carbohydrate components in glycoproteins using gas-liquid chromatography. Anal Biochem 123, 336-341.

Collins, M. D. (1985). Structure of thermoplasmaquinone from Thermoplasma acidophilum. FEMS Microbiol Lett 28, 21-23.

Darland, G., Brock, T. D., Samsonoff, W. \& Conti, S. F. (1970). A thermophilic, acidophilic Mycoplasma isolated from a coal refuse pile. Science 170, 1416-1418.

De Ley, J., Cattoir, H. \& Reynaerts, A. (1970). The quantitative measurement of DNA hybridization from renaturation rates. Eur $J$ Biochem 12, 133-142.

Dopson, M., Baker-Austin, C., Hind, A., Bowman, J. P. \& Bond, P. L. (2004). Characterization of Ferroplasma isolates and Ferroplasma acidarmanus sp. nov., extreme acidophiles from acid mine drainage and industrial bioleaching environments. Appl Environ Microbiol 70, 2079-2088.

Edwards, K. J., Bond, P. L., Gihring, T. M. \& Banfield, J. F. (2000). An archaeal iron-oxidizing extreme acidophile important in acid mine drainage. Science 287, 1796-1799.

Ferrer, M., Golyshina, O. V., Beloqui, A., Golyshin, P. N. \& Timmis, K. N. (2007). The cellular machinery of Ferroplasma acidiphilum is iron-protein-dominated. Nature 445, 91-94.

Golyshina, O. V. \& Timmis, K. N. (2005). Ferroplasma and relatives, recently discovered cell wall-lacking archaea making a living in extremely acid, heavy metal-rich environments. Environ Microbiol 7, 1277-1288.

Golyshina, O. V., Pivovarova, T. A., Karavaiko, G. I., Kondrat'eva, T. F., Moore, E. R. B., Abraham, W. R., Lünsdorf, H., Timmis, K. N., Yakimov, M. M. \& Golyshin, P. N. (2000). Ferroplasma acidiphilum gen. nov., sp. nov., an acidophilic, autotrophic, ferrous-ironoxidizing, cell-wall-lacking, mesophilic member of the Ferroplasmaceae fam. nov., comprising a distinct lineage of the Archaea. Int $J$ Syst Evol Microbiol 50, 997-1006.

Hawkes, R. B., Franzmann, P. D., O’Hara, G. \& Plumb, J. J. (2006). Ferroplasma cupricumulans sp. nov., a novel moderately thermophilic, acidophilic archaeon isolated from an industrial-scale chalcocite bioleach heap. Extremophiles 10, 525-530.

Hawkes, R. B., Franzmann, P. D., O’Hara, G. \& Plumb, J. J. (2008). Ferroplasma cupricumulans sp. nov. In List of New Names and New Combinations Previously Effectively, but not Validly, Published, Validation List no. 119. Int J Syst Evol Microbiol 58, 1-2.

Huber, H. \& Stetter, K. O. (2006). The order Thermoplasmatales. In The Prokaryotes, 3rd edn, vol. 3, pp. 101-112. Edited by M. Dworkin, S. Falkow, E. Rosenberg, K. H. Schleifer \& E. Stackebrandt. New York: Springer.

Huß, V. A. R., Festl, H. \& Schleifer, K. H. (1983). Studies on the spectrophotometric determination of DNA hybridization from renaturation rates. Syst Appl Microbiol 4, 184-192.

Itoh, T., Yoshikawa, N. \& Takashina, T. (2007). Thermogymnomonas acidicola gen. nov., sp. nov., a novel thermoacidophilic, cell wall-less archaeon in the order Thermoplasmatales, isolated from a solfataric soil in Hakone, Japan. Int J Syst Evol Microbiol 57, 2557-2561.

Kumar, S., Tamura, K. \& Nei, M. (2004). MEGA3: integrated software for molecular evolutionary genetics analysis and sequence alignment. Brief Bioinform 5, 150-163. 
Lünsdorf, H., Strömpl, C., Osborn, A. M., Bennasar, A., Moore, E. R. B., Abraham, W.-R. \& Timmis, K. N. (2001). Approach to analyze interactions of microorganisms, hydrophobic substrates, and soil colloids leading to formation of composite biofilms, and to study initial events in microbiogeological processes. Methods Enzymol 336, 317-331.

Mesbah, M., Premachandran, U. \& Whitman, W. B. (1989). Precise measurement of the $\mathrm{G}+\mathrm{C}$ content of deoxyribonucleic acid by high-performance liquid chromatography. Int J Syst Bacteriol 39, 159-167.

Schleper, C., Puehler, G., Holz, I., Gambacorta, A., Janekovic, D., Santarius, U., Klenk, H. P. \& Zillig, W. (1995). Picrophilus gen. nov., fam. nov.: a novel aerobic, heterotrophic, thermoacidophilic genus and family comprising archaea capable of growth around $\mathrm{pH} 0$. J Bacteriol 177, 7050-7059.

Schleper, C., Pühler, G., Klenk, H.-P. \& Zillig, W. (1996). Picrophilus oshimae and Picrophilus torridus fam. nov., gen. nov., sp. nov., two species of hyperacidophilic, thermophilic, heterotrophic, aerobic archaea. Int J Syst Bacteriol 46, 814-816.
Segerer, A., Langworthy, T. A. \& Stetter, K. O. (1988). Thermoplasma acidophilum and Thermoplasma volcanium sp. nov. from solfatara fields. Syst Appl Microbiol 10, 161-171.

Shimada, H., Shida, Y. \& Nemioto, N. (2001). Quinone profiles of Thermoplasma acidophilum HO-62. J Bacteriol 183, 1462-1465.

Spurr, A. R. (1969). A low viscosity epoxy resin embedding medium for electron microscopy. J Ultrastruct Res 26, 31-43.

Swain, M., Brisson, J.-B., Sprott, G. D., Cooper, F. P. \& Patel, G. B. (1997). Identification of $\beta$-L-gulose as the sugar moiety of the main polar lipid Thermoplasma acidophilum. Biochim Biophys Acta 1345, 56-64.

Tamaoka, J. \& Komagata, K. (1984). Determination of DNA base composition by reversed-phase high-performance liquid chromatography. FEMS Microbiol Lett 25, 125-128.

Wayne, L. G., Brenner, D. J., Colwell, R. R., Grimont, P. A. D., Kandler, O., Krichevsky, M. I., Moore, L. H., Moore, W. E. C., Murray, R. G. E. \& other authors (1987). International Committee on Systematic Bacteriology. Report of the ad hoc committee on reconciliation of approaches to bacterial systematics. Int J Syst Bacteriol 37, 463-464. 